\title{
Chapter 10 \\ How Closely Is Potassium Mass Balance Related to Soil Test Changes?
}

\author{
David W. Franzen, Keith Goulding, Antonio P. Mallarino, and \\ Michael J. Bell
}

\begin{abstract}
The exchangeable fraction of soil potassium $(\mathrm{K})$ has been viewed as the most important source of plant-available K, with other sources playing smaller roles that do not influence the predictive value of a soil test. Thus, as $\mathrm{K}$ mass balance changes, the soil test should change correspondingly to be associated with greater or reduced plant availability. However, soil test changes and the availability of $\mathrm{K}$ to plants are influenced by many other factors. This chapter reviews research on soil test $\mathrm{K}$ changes and the relation to crop uptake and yield. A mass-balance relationship is rarely achieved from the measurement of exchangeable $\mathrm{K}$ because of the potential for buffering of $\mathrm{K}$ removal from structural $\mathrm{K}$ in feldspars and from interlayer $\mathrm{K}$ in primary and secondary layer silicates. Similarly, surplus K additions can be fixed in interlayer positions in secondary layer silicates, or potentially sequestered in sparingly soluble neoformed secondary minerals, neither of which is measured as exchangeable K. In addition, soil moisture, temporal differences in exchangeable $\mathrm{K}$ with $\mathrm{K}$ uptake by crops, $\mathrm{K}$ leaching from residues, clay type, organic matter contribution to the soil CEC, and type of $\mathrm{K}$ amendment confound attempts to relate $\mathrm{K}$ additions and losses with an exchangeable $\mathrm{K}$ soil test. Research is needed to create regionally specific $\mathrm{K}$ soil test procedures that can predict crop response for a subset of clays and K-bearing minerals within specific cropping systems.
\end{abstract}

D. W. Franzen $(\bowtie)$

North Dakota State University, Fargo, ND, USA

e-mail: david.franzen@ndsu.edu

K. Goulding

Rothamsted Research, Harpenden, Hertfordshire, UK

e-mail: keith.goulding@ rothamsted.ac.uk

A. P. Mallarino

Department of Agronomy, Iowa State University, Ames, IA, USA

e-mail: apmallar@iastate.edu

M. J. Bell

School of Agriculture and Food Sciences, The University of Queensland, Brisbane, QLD,

Australia

e-mail: m.bell4@uq.edu.au

(C) The Author(s) 2021

T. S. Murrell et al. (eds.), Improving Potassium Recommendations for Agricultural

Crops, https://doi.org/10.1007/978-3-030-59197-7_10 


\subsection{Introduction}

If $\mathrm{K}$ nutrition of crops were a simple system, with additions of $\mathrm{K}$ held by the soil and released as needed, then the $\mathrm{K}$ supply and relative availability could be accurately predicted by a simple soil extraction. However, the reality is that the prediction of $\mathrm{K}$ availability can be as difficult to understand as that of $\mathrm{N}$ and $\mathrm{P}$. While $\mathrm{N}$ availability prediction is confounded by temperature, rainfall, soil moisture condition, biological transformation through oxidation and reduction products, and nutrient cycling in plants and soil organisms, $\mathrm{K}$ nutrition is affected by most of those factors, with the exception of biological redox products, but with the addition of the physical and chemical properties of the soil and its mineralogy, mainly of the K-bearing minerals. Although students are often taught that the exchangeable K "pool" in the soil is the major source of plant-available $\mathrm{K}$ and the reservoir for most fertilizer $\mathrm{K}$ applied, the reality is that the equilibrium reactions between the soil solution $\mathrm{K}$, adsorbed $\mathrm{K}$, interlayer $\mathrm{K}$ in primary and secondary layer silicates and in structural pools in minerals such as potassium feldspar can be rapid and have a significant influence on the soil test and crop production.

The dynamics of sources of $\mathrm{K}$ and interactions between sources have been summarized and described in many diagrams, mostly in the flowchart in Fig. 7.1 developed after the 2017 Frontiers in Potassium Science Workshop in Rome (Bell et al. 2017a, b), and discussed in detail in Chap. 7 of this book. Discussion of the dynamics depicted in Fig. 10.1 suggests that equilibria between exchangeable K, solution $\mathrm{K}$, and $\mathrm{K}$ additions as fertilizer are always rapid, with each being measured in hours or days, not weeks, months, and years (Krauss and Johnston 2002). We will attempt to capture the difficulty of using a mass-balance approach to crop K nutrition from the biological, temporal, clay mineral, and primary mineral components depicted in Fig. 10.1.

\subsection{The Mass-Balance Approach}

The basic premise of a mass-balance approach is that when $\mathrm{K}$ is added to the soil, most often as soluble $\mathrm{K}$ fertilizers, such as potassium chloride or potassium sulfate, the $\mathrm{K}$ ions are retained at the soil cation exchange sites with the potential to be released later into the soil solution and taken up by the crop. The most commonly used measurement techniques for quantifying $\mathrm{K}$ on the exchange sites is displacement with $\mathrm{NH}_{4}^{+}$in a variety of extraction techniques, such as $1 \mathrm{M}$-ammonium acetate. In the USA and the UK, the mass-balance approach is a common strategy for $\mathrm{K}$ fertilization, particularly where a buildup and maintenance approach to crop fertilization is recommended, but also to maintain desirable soil-test values when response-based information is used to decide fertilization rates for low-testing soils. In the strict buildup-maintenance approach, the fertilizers are applied at rates intended to replace crop grain or forage removal and, if necessary, the soil test is 


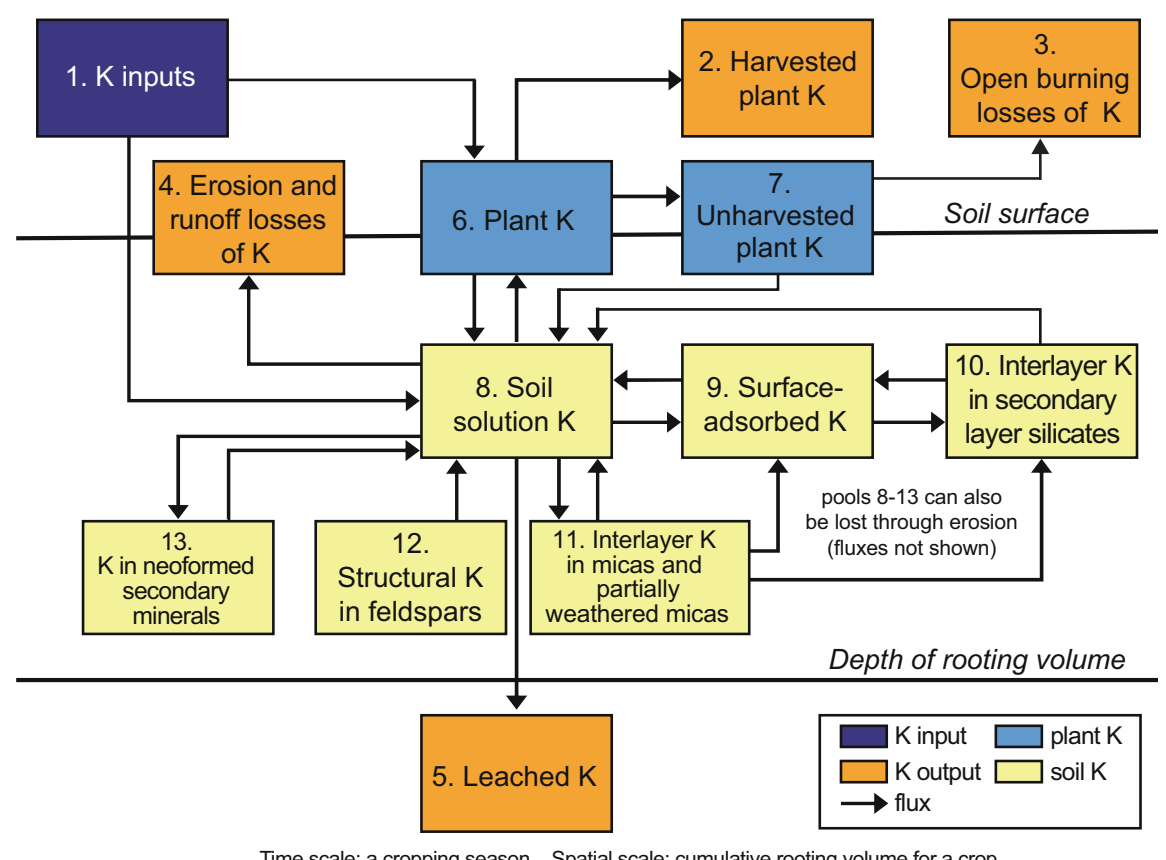

Fig. 10.1 Sources of soil $\mathrm{K}$ and interactions between sources. (Chap. 7)

increased through the addition of extra fertilizer to attain a certain soil test concentration regarded as critical or optimum for K supply. In Illinois, USA for example, it is assumed that the amount of fertilizer $\mathrm{K}$ recommended to increase the $\mathrm{K}$ soil test by $1 \mathrm{mg} \mathrm{kg}^{-1}$ in the medium to higher CEC (cation exchange capacity) soils of central and northern Illinois is about $10 \mathrm{~kg} \mathrm{~K} \mathrm{ha}^{-1}$ (Fernandez and Hoeft 2015), but this is a broad average. In contrast, Missouri USA recommendations indicate that $63 \mathrm{~kg} \mathrm{~K}$ $\mathrm{ha}^{-1}$ will increase $\mathrm{K}$ soil test by $1 \mathrm{mg} \mathrm{kg}^{-1}$ (Buchholz 2004). In the UK, a rough estimate of soil test increase with $\mathrm{K}$ addition is that $3-5 \mathrm{~kg} \mathrm{~K} \mathrm{ha}^{-1}$ results in a $1 \mathrm{mg} \mathrm{kg}^{-1}$ increase in soil test $\mathrm{K}$ (Potash Development Association 2011). Since these recommendations are empirically based within the region affected, one can assume that there are soil characteristics that contribute to the different responses of the resulting soil test $\mathrm{K}$ with $\mathrm{K}$ fertilizer addition.

In Illinois, the mean fertilizer K application rates and mean yields in two 12.5 ha fields were documented for 40 years starting in 1960 (Franzen 1993). The rates of applied K were greater than crop removal until 1982, which resulted in increased soil test K concentrations. From 1982 until 1992 no additional fertilizer K was added and $\mathrm{K}$ removal by corn (Zea mays L.) and soybean (Glycine max L. Merr.) harvests was estimated for all years. The results are shown in Fig. 10.2. The rate at which the soil $\mathrm{K}$ test increased with $\mathrm{K}$ fertilizer addition was different from the rate of decline with crop removal. The results show a "hysteresis" effect. At a site near Thomasboro, IL, 
D. W. Franzen et al.
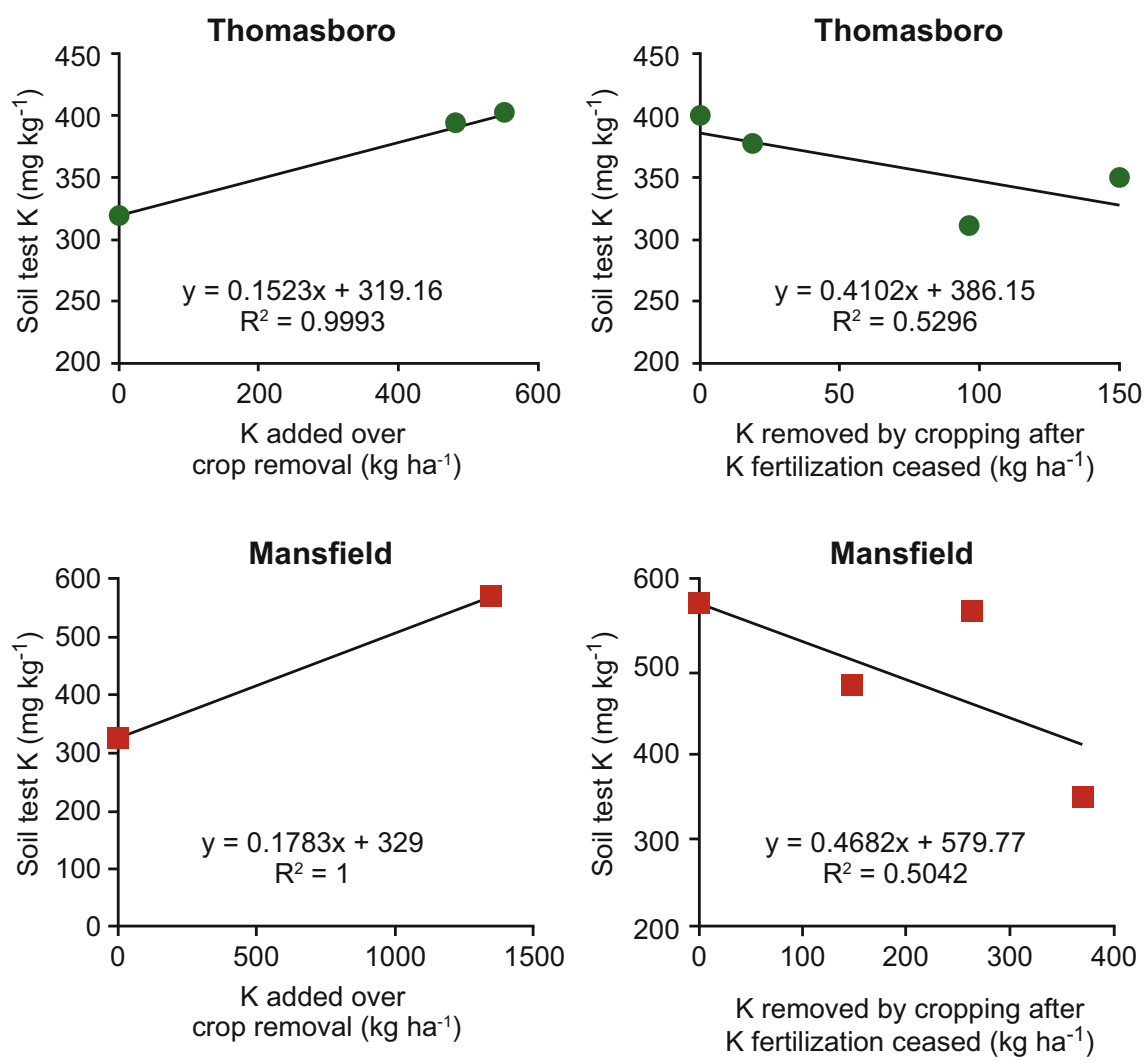

Fig. 10.2 Cumulative net $\mathrm{K}$ added per hectare to Thomasboro (upper left) and Mansfield (lower left) Illinois 12.5 ha fields over a period of years, compared to $\mathrm{K}$ removed by crop removal at Thomasboro (upper right) and Mansfield (lower right) after K fertilization ceased in 1982 at both sites

USA, the rate of soil test $\mathrm{K}$ increase was $1 \mathrm{mg} \mathrm{kg}^{-1}$ for $6.6 \mathrm{~kg} \mathrm{~K} \mathrm{ha}^{-1}$ added as fertilizer over crop removal. After $\mathrm{K}$ fertilization ceased, the rate of soil test $\mathrm{K}$ decline was $1 \mathrm{mg} \mathrm{kg}^{-1}$ for $2.4 \mathrm{~kg} \mathrm{~K} \mathrm{ha}^{-1}$ in crop removal. At a site near Mansfield, IL, USA, the rate of soil test $\mathrm{K}$ increase was $1 \mathrm{mg} \mathrm{kg}^{-1}$ for $5.8 \mathrm{~kg} \mathrm{ha}^{-1}$ added as fertilizer over crop removal. After $\mathrm{K}$ fertilization ceased, the rate of soil test $\mathrm{K}$ decline at Mansfield was $1 \mathrm{mg} \mathrm{kg}^{-1}$ for $2.2 \mathrm{~kg} \mathrm{~K} \mathrm{ha}^{-1}$ in crop removal.

In the Parana state of Brazil, a K application experiment on 12 tropical soils with basalt, shale, sandstone, and alluvial parent materials resulted in reductions in exchangeable $\mathrm{K}$ after the initial 2-year soybean/pearl millet cropping sequence with comparably small reductions in exchangeable $\mathrm{K}$ during the following 4 years (Steiner et al. 2015). In K-fertilized treatments in the same soils, exchangeable K increased in all soils and reached a plateau of values after the first two crops. The subsequent exchangeable $\mathrm{K}$ values were similar through the following four crop years despite continued $\mathrm{K}$ fertilization. Thus, the mass-balance approach appeared to 
be operating during the first 2 years, but not in the subsequent 4 years. What was not considered by the researchers, but has been observed in Australia (Bell et al. 2009) is that $\mathrm{K}$ can be extracted by roots from deeper soil layers not measured in traditional soil testing approaches (e.g., the cultivated layer), especially when surface soil K availability is depleted (unfertilized treatments), or leached to deeper soil depths and retained at these depths when surplus K applications are made (Bell et al. 2017a, b). In both instances, the surface layer soil $\mathrm{K}$ tests may remain relatively unchanged. In unfertilized treatments, the $\mathrm{K}$ uptake from deeper soil layers, residue return to surface layers and the relatively small proportion of biomass $\mathrm{K}$ actually removed in harvested grain (especially in cereals) will help to stabilize topsoil $\mathrm{K}$ concentrations. Conversely, in fertilized $\mathrm{K}$ treatments, the $\mathrm{K}$-specific adsorption sites may become saturated with $\mathrm{K}$, with subsequent $\mathrm{K}$ fertilization resulting in leaching of surplus K into subsoils. Bell et al. (2009) support K determination in their soils at deeper depths than those usually considered to account for these aspects.

In Alabama, USA, Cope (1981) summarized 50 years of $\mathrm{K}$ fertilization in four sandy low CEC $\left(<5 \mathrm{cmol}(+) \mathrm{kg}^{-1}\right)$ soils and one silt loam soil with CEC about $10 \mathrm{cmol}(+) \mathrm{kg}^{-1}$. He found that, in the unfertilized plots, the soil test $\mathrm{K}$ concentration initially decreased, but reached an equilibrium after 28 years at most; the second sampling being in 1957, 28 years following study initiation. A K fertilizer application rate of $18 \mathrm{~kg} \mathrm{~K} \mathrm{ha}^{-1}$ resulted in no soil test change, while $\mathrm{K}$ application rates greater than $18 \mathrm{~kg} \mathrm{~K} \mathrm{ha}^{-1}$ resulted in soil test $\mathrm{K}$ increases in all soils. The soil test $\mathrm{K}$ during and at the termination of the experiment was related to the CEC of the soils. So, in this experiment with kaolinitic and quartz-based soil parent material soils, the mass-balance approach to $\mathrm{K}$ fertilization was effective.

In a summary of a series of five 16-year $\mathrm{K}$ fertilizer rate experiments in Iowa (Villavicencio 2011), researchers found that when $\mathrm{K}$ was not applied, the rate of decrease in soil test $\mathrm{K}(15-\mathrm{cm}$ depth) did not match the $\mathrm{K}$ removal rate from the grain in the short term (Fig. 10.3). There was very high temporal soil test $\mathrm{K}$ variability from year to year that the yearly $\mathrm{K}$ removal in the grain harvest seldom explained. The soil test and $\mathrm{K}$ removal trends approximately matched over several years, however, except when decreasing soil-test $\mathrm{K}$ reached a minimum plateau at around $120 \mathrm{mg} \mathrm{kg}^{-1}$. At this point, in spite of continuous $\mathrm{K}$ removal, the soil test decrease may have been buffered by soil release from other pools in the topsoil or subsoil, or supplemented by deeper profile soil $\mathrm{K}$. The soil clays at the experimental sites were dominantly smectitic. In addition, as the soil test $\mathrm{K}$ concentration decreased, corn and soybean yield was not always increased by $\mathrm{K}$ fertilization. Yield increases were frequent and common only at three sites where soil test $\mathrm{K}$ was initially $<170 \mathrm{mg} \mathrm{kg}{ }^{-1}$, which placed them in Iowa State University recommendation categories of "optimal" and lower.

Results from the then 130-year-old Garden Clover experiment at Rothamsted, UK showed that the change in exchangeable $\mathrm{K}$ as a percentage of a positive $\mathrm{K}$ balance was on average only $39 \%$ of the K applied, while it was only $38 \%$ of the K removed when the $\mathrm{K}$ balance was negative (McEwen et al. 1984).

Thirty-year experiments in the UK, Germany, and Poland compared K balances with or without K fertilizer or farmyard manure (Blake et al. 1999). The recovery 
Fig. 10.3 Trends over time for cumulative $\mathrm{K}$ removal with grain harvest and soiltest $\mathrm{K}$ for samples collected each year from the non-fertilized plots in longterm Iowa $\mathrm{K}$ fertilization experiments. NERF, NIRF, NWRF, SERF, and SWRF are different experiment sites throughout Iowa. (from Villavicencio 2011)

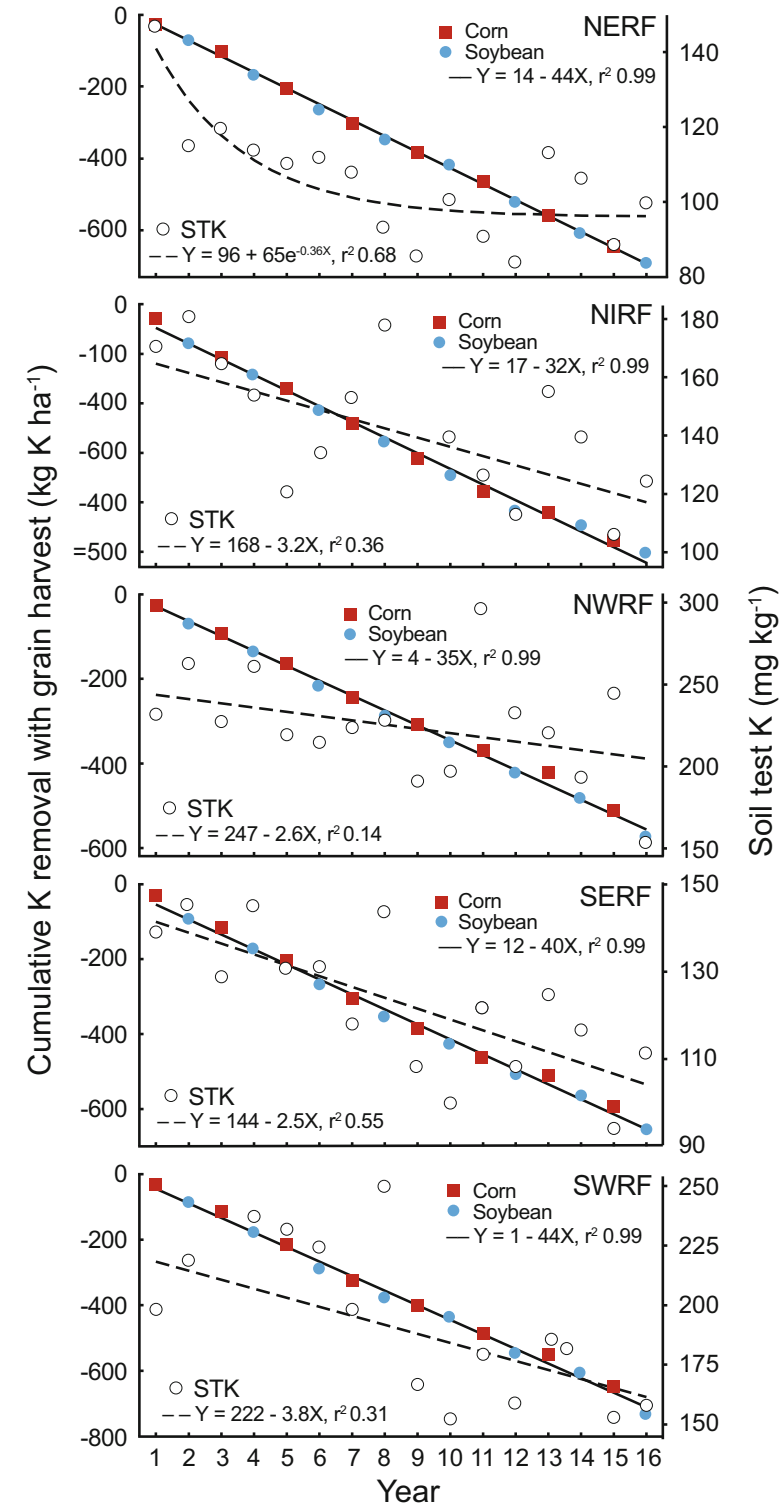

rate of $\mathrm{K}$ from mineral fertilizers was less than $62 \%$ and decreased with increasing CEC. At Rothamsted, the fixation capacity of the clays was also a significant factor. In Germany and Poland, there was lower utilization of fertilizer $\mathrm{K}$ when manures were applied because $\mathrm{K}$ from manures were taken up in preference. A Canadian study of the kinetics of $\mathrm{K}$ adsorption by organic matter showed that organic matter adsorbed- $\mathrm{K}$ is much more accessible by plants and adsorption of $\mathrm{K}$ onto organic matter exchange sites is more rapid (Wang and Huang 2001). These experiments 
again showed that a mass-balance approach is not entirely useful because the source of $\mathrm{K}$, the characteristics of the CEC sites, and the soils interact to confound any "check-book" balance that may be attempted. An attempt to understand this was suggested by Addiscott and Johnston (1971). They proposed that by increasing the soil organic matter content through application of farmyard manure, along with regulating the soil moisture supply to minimize $\mathrm{K}$ leaching, more $\mathrm{K}$ would be retained on the organic matter exchange sites and less would be moved into non-exchangeable forms.

Despite all these problems, the mass-balance approach is still the basis for many national and regional recommendation systems as noted above. For example, Dobermann et al. (1996) recommended that efficient $\mathrm{K}$ management for rice should be based on the $\mathrm{K}$ balance, but modified by the achievable yield target and the effective K-supplying power of the soil.

A variation on the mass-balance approach is the "Ideal Soil" CEC balance ratios championed by Bear in New Jersey (1951) and later by Albrecht at the University of Missouri (Albrecht 1975). The premise of this approach is that the amount of $\mathrm{K}$ in the soil is not as important as the ratio of $\mathrm{K}$ to that of the other major cations, $\mathrm{Ca}$ and $\mathrm{Mg}$. A commonly used ratio of $\mathrm{K}$ in an "ideal" soil is somewhere between 2 and $5 \%$ of the base exchange capacity (Graham 1959). Although this approach is still used in parts of the USA by fertilizer and amendment sales organizations, its scientific validity has been refuted. A review of the use of this Base Cation Saturation Ratio approach was authored by Kopittke and Menzies (2007). The review concludes that the data do not support the existence of an ideal ratio and that its use would result in inefficient use of resources. The Albrecht approach has also been strongly challenged in the popular agricultural press by a number of agronomists (Miles et al. 2013).

\subsection{Temporal Nature of K Soil Test Values}

The previous studies have demonstrated that a purely mass-balance approach does not always account for soil test differences in exchangeable $\mathrm{K}$ values and that the use of some ideal ratio of cations in directing $\mathrm{K}$ application is not effective. The deficiency of a mass-balance approach is also reinforced by the temporal nature of exchangeable $\mathrm{K}$ soil test values that have been recorded in soils with mineralogy that supports K fixation and release. A 20-year study using twice-monthly soil sampling at the $0-15 \mathrm{~cm}$ depth for exchangeable $\mathrm{K}$ (1M-ammonium acetate) was conducted at Urbana, IL and Brownstown, IL, USA. Most of this data was lost and never published, but 9 years of the Urbana work was published in 2005 (Peck and Sullivan 1995). Using tabular values, Franzen (2011) imposed a seasonal repeated analysis using the statistical package SAS (PROC UCM time series analysis using 24 data points per cycle) to the data and found that the relative $\mathrm{K}$ values were related to soil moisture at the time of sampling. Starting on April 1, 1986, in each year (Fig. 10.4), the extractable $\mathrm{K}$ is highest in winter when soil moisture is greatest and lowest in late 


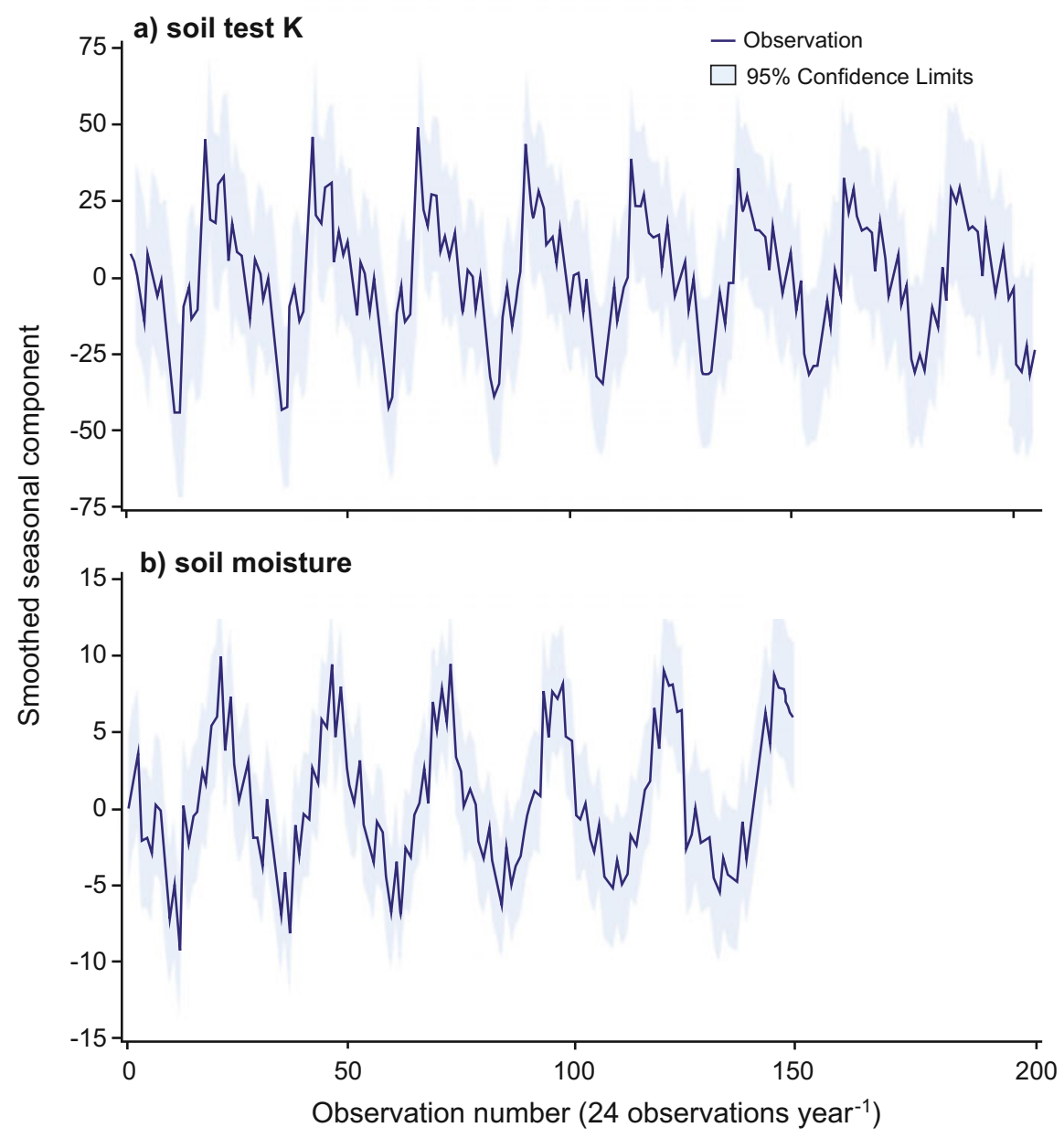

Fig. 10.4 (a) Soil test K. (b) Soil moisture. Seasonality of soil K (top image) over 9 years, compared with soil moisture (bottom image over 6 years. Soil samples $0-15 \mathrm{~cm}$ obtained twice monthly from April 1, 1986, through 1994. Soil moisture was available for the first 6 years only. (from Franzen 2011)

summer when the soil is driest and $\mathrm{K}$ supply was decreased by corn uptake. The soils in this study were dominated by smectite clay.

Recent K studies in North Dakota, USA using illite-dominant and smectitedominant clays have indicated that the seasonal variation of the $\mathrm{K}$ soil tests is minor on soils with a smectite/illite ratio $<3.5$, but relatively high on soils with a smectite/illite ratio $>3.5$ (Fig. 10.5). The North Dakota climate is not favorable for winter soil sampling; however, the North Dakota data shows the greatest $\mathrm{K}$ extraction by $1 \mathrm{M}$-ammonium acetate in early spring, with values decreasing as the season 


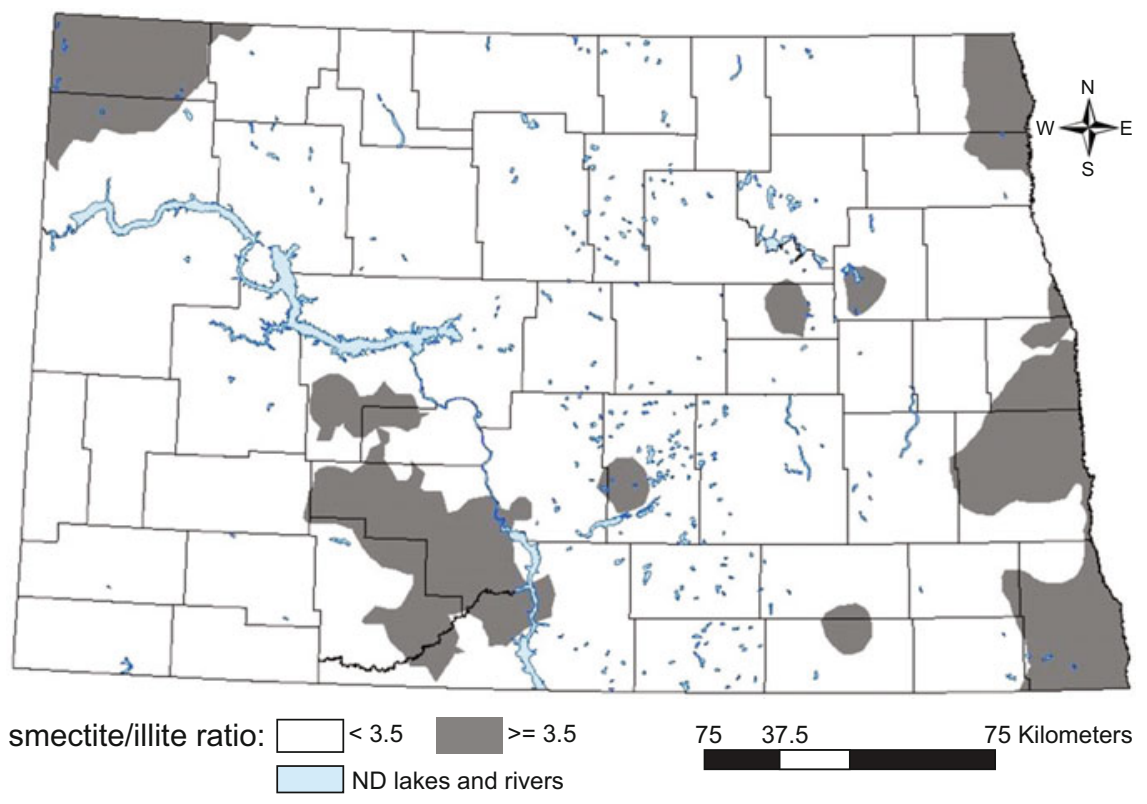

Fig. 10.5 Smectite/illite ratio in the clay fraction of North Dakota soils from a state-wide soil sampling survey conducted spring, 2017. (Franzen, unpublished data)

progresses to drier months. These data are not as clearly related to soil moisture as those from Illinois. To determine whether the seasonality was related to crop uptake, both fallow and cropped (corn) check plots were sampled twice each month from planting to harvest. The seasonality of the $\mathrm{K}$ test and its decrease through the growing season was present at both the smectitic and illitic sites when the soils were cropped (Fig. 10.6). When the soils had a smectite/illite ratio $<3.5$, the $\mathrm{K}$ test tended to remain relatively constant, while in a soil with a smectite/illite ratio $>3.5$, the $\mathrm{K}$ test levels tended to decrease in the drier part of the summer (between 12 and 17 weeks after planting) and increase when soils were moist (week 10, 18, 19). This is consistent with fixation during dry conditions, and release when the soils are moist. The fixation in these soils is temporary, and release and fixation of $\mathrm{K}$ are relatively rapid and reversible based on these data.

\subsection{Crop Residue Recycling in K Mass-Balance Considerations}

Part of the reason for the apparent seasonality in the $\mathrm{K}$ test is uptake of $\mathrm{K}$ by the crop and its release back into the soil after physiological maturity. Mean corn vegetative $\mathrm{K}$ content at physiological maturity in a series of Iowa $\mathrm{K}$ rate experiments (Oltmans and Mallarino 2015) was $93 \mathrm{~kg} \mathrm{~K} \mathrm{ha}^{-1}$ for sites with a K yield response and $101 \mathrm{~kg} \mathrm{~K}$ 

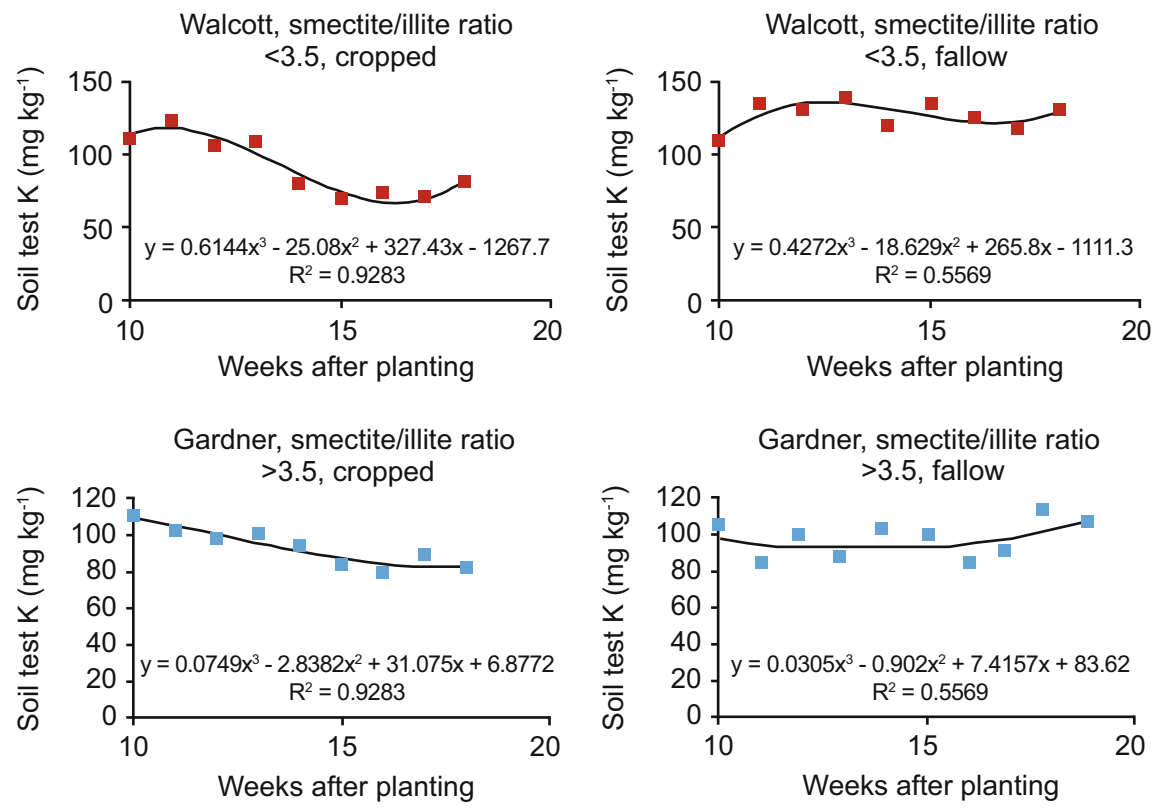

Fig. 10.6 Change in dry soil test $\mathrm{K}$ concentrations from 10 weeks after planting to 20 weeks after planting in a soil with a smectite/illite ratio in the soil clay fraction $<3.5$ and a soil with a smectite/ illite ratio $>3.5$ under corn and fallow. (Breker and Franzen, unpublished; North Dakota, USA)

$\mathrm{ha}^{-1}$ for sites with no $\mathrm{K}$ response. For soybean, the mean $\mathrm{K}$ accumulated in vegetative parts at physiological maturity was $95 \mathrm{~kg} \mathrm{ha}^{-1}$ for all sites. From physiological maturity, $\mathrm{K}$ is lost from the vegetative portion of the plants, with mean $\mathrm{K}$ in vegetative tissues in corn at harvest at sites with a $\mathrm{K}$ yield response of $66 \mathrm{~kg} \mathrm{ha}^{-1}$, and $67 \mathrm{~kg} \mathrm{ha}^{-1}$ at sites with no $\mathrm{K}$ response. In soybean, the mean residue content of $\mathrm{K}$ declined to $41 \mathrm{~kg} \mathrm{ha}^{-1}$ at harvest. These data indicate that soil sampling at physiological maturity, which is a practice utilized by some crop consultants, may result in lower soil test $\mathrm{K}$ values than if the samples were taken at harvest or later in the fall. The residue $\mathrm{K}$ content of corn and soybean was about $25 \mathrm{~kg} \mathrm{ha}^{-1}$ and $54 \mathrm{~kg} \mathrm{ha}^{-1}$ less, respectively, at harvest compared to physiological maturity. Losses from crop residues also contribute to the soil $\mathrm{K}$ pool.

The soybean residue in the Oltmans and Mallarino (2015) study continued to lose $\mathrm{K}$ throughout the fall until late January, when the $\mathrm{K}$ content reached about $10 \mathrm{~kg} \mathrm{ha}^{-1}$. Loss of $\mathrm{K}$ from corn residue steadily declined to about $30 \mathrm{~kg} \mathrm{ha}^{-1}$ in early December, then decreased again during the spring thaw. Precipitation following physiological maturity explained much of the residue $\mathrm{K}$ decline. Across all sites, the soil test $\mathrm{K}$ concentration (15-cm depth) was higher in spring than in the fall, and the magnitude of difference was linearly related with the $\mathrm{K}$ loss from residue, although the relationship was much better in soybean residue $\left(r^{2} 0.56\right)$ than in corn residue $\left(r^{2}\right.$ $0.16)$. These data indicate that soil sampling at physiological maturity, which is a practice utilized by some crop consultants, may result in lower soil test $\mathrm{K}$ values than 
if the samples were taken at harvest or later in the fall due to $\mathrm{K}$ leaching into the soil from plant residues.

The cycling of $\mathrm{K}$ from crop residue back to soil is a noted component of many plant ecosystems (Jobbagy and Jackson 2004). Plants mobilize K from deeper in the soil in natural systems, and their leaves and other vegetative parts are returned to the soil, resulting in an accumulation of $\mathrm{K}$ near the surface. Corn and soybean and other crops also return $\mathrm{K}$ to the soil surface; corn returning a much larger percentage than soybean (Oltmans and Mallarino 2015). Most grain crops at harvest, including wheat and corn, do not contain high $\mathrm{K}$ concentrations in the seed that is removed, with soybean being an exception.

Although there is often a relationship between exchangeable $\mathrm{K}$ and crop yield response to $\mathrm{K}$ addition, the relationship is less frequent with absolute crop yield. The relationship is also seldom mass-balance based, as the previous discussion would indicate. In soils with a sandy texture (Mendes et al. 2016; Alfaro et al. 2004) and in clay soils with deep cracks followed by high rainfall (Alfaro et al. 2004), K losses from the soil system by leaching are common, resulting in much apparently available exchangeable $\mathrm{K}$ being unavailable to the crop early in the growing season; this can result in a yield penalty. In high-clay soils with significant content of smectitic clays, deep cracks, sometimes over $1 \mathrm{~m}$ in depth, may form. During rainfall, some of the topsoil washes into the cracks, resulting in loss of $\mathrm{K}$ to deeper soil depths (Alfaro et al. 2004). In most soils, the $\mathrm{K}$ leached from the $0-15 \mathrm{~cm}$ typical K-sampling depth would be retained at deeper soil depths; therefore, a multi-depth approach in soils with surface layer $\mathrm{K}$ leaching potential may be important to explaining mass-balance and response to $\mathrm{K}$ at lower soil test values.

\subsection{Clay Chemistry and K Response}

According to research by Sharpley (1989) in his study of 102 soils from the continental US and Puerto Rico, water-soluble K was closely related to exchangeable $\mathrm{K}$ within soils of similar clay-type, but not between clay-types. The release of $\mathrm{K}$ from exchangeable sources into solution increased from smectitic to "mixed" clays to kaolinitic clays. Sharpley recommended that an analysis of exchangeable K and K reserves (as nitric acid-extractable $\mathrm{K}$ ) would provide a better indication of $\mathrm{K}$ supply for crops. This had been suggested by Goulding (1984) and Goulding and Loveland (1986) and is discussed in detail in Chaps. 7 and 8 in this book.

An Australian study reported $\mathrm{K}$ fertilization practices in Red Ferrosol, low CEC soils, and Black and Grey Vertisols, which are moderate to high clay-content soils. Analyses of exchangeable $\mathrm{K}$, soil solution $\mathrm{K}$, and the activity of $\mathrm{K}$ in soil solution varied 6-7-fold between soil types (Bell et al. 2009). The management of $\mathrm{K}$ for optimal crop production varied with soil. The Vertisols had a high $\mathrm{K}$ buffer capacity $\left(\mathrm{BC}_{\mathrm{K}}\right)$ and applications of $\mathrm{K}$ were not as effective at increasing crop $\mathrm{K}$ accumulation as those in the low CEC Red Ferrosols, where $\mathrm{BC}_{\mathrm{K}}$ was significantly lower. A better $\mathrm{K}$ fertilization approach for the Vertisols was to apply a $\mathrm{K}$ fertilizer in concentrated 
bands rather than a broadcast application that resulted in lower soil solution $\mathrm{K}$ concentrations within the soil volume. In the high clay Vertisols with high CEC (50-60 cmol(+) $\left.\mathrm{kg}^{-1}\right)$, a deep band of $\mathrm{K}$ with $\mathrm{N}$ and $\mathrm{P}$ was more effective at overcoming $\mathrm{K}$ deficiency due to root proliferation around the $\mathrm{K}$ band (Chap. 12).

In a study of $23 \mathrm{~K}$ rate experiments in North Dakota in 2014 and 2015, the response of corn at sites below the current exchangeable K critical level of $150 \mathrm{mg} \mathrm{K}$ $\mathrm{kg}^{-1}$ was not predicted at 10 sites (Table 10.1). The relative corn yield of the unfertilized check in relation to soil test $\mathrm{K}$ at these sites is shown in Fig. 10.7, with the relationship between exchangeable $\mathrm{K}$ and relative yield very weak. A multiple regression analysis of relative yield with the potassium feldspar concentration of the mineral fraction of the 23 sites and the relative clay mineral percentage of the clay fraction is shown in Table 10.2. This analysis suggested that the best prediction of yield response to $\mathrm{K}$ fertilization in these North Dakota soils would need to consider both clay mineralogy and the soil test $\mathrm{K}$ concentration. Unfortunately, many agricultural regions do not have access to clay mineralogy data, and so these refinements can be difficult to implement.

Using a Ward minimum variance clustering technique, the sites clustered into those with smectite/illite ratios $<3.5$ and those $>3.5$ (Fig. 10.5). Using K response data from the sites falling into those categories, the resulting responses indicated that a critical level of $150 \mathrm{mg} \mathrm{K} \mathrm{kg}^{-1}$ was appropriate for site with a smectite/illite ratio < 3.5 and a critical level of $200 \mathrm{mg} \mathrm{K} \mathrm{kg}^{-1}$ was more appropriate for sites with a smectite/illite ratio $>3.5$ (Fig. 10.8).

Different articles in this book focus directly on the importance of different soil K pools (Bell et al. 2017a, Chap. 7) in relation to bioavailability, and on the relationship between various soil tests and plant-availability of soil K (Bell et al. 2017b, Chap. 8), but it is relevant to mention here some concepts and findings. Potassium application and its interaction with clays, particularly a change in clay type with $\mathrm{K}$ addition or loss, has been documented and could confound expected $\mathrm{K}$ test results. Barre et al. (2007) hypothesized that the illite-dominance of prairie soils in temperate regions was due to the production and stabilization of illite from $\mathrm{K}$ redistributed from deeper soil strata to surface strata through root uptake and residue deposition to the surface. Barre et al. (2009) provided a brief review of studies supporting the hypothesis of illite construction and deconstruction under prairie vegetation and offered a model that might predict clay stability under $\mathrm{K}$ addition or loss through intensive cropping without adequate $\mathrm{K}$ replenishment. A study from China in a loess-derived soil containing illite and chlorite focused on topsoil total $\mathrm{K}$ compared to a reduction in exchangeable $\mathrm{K}$ during 15 years of continuous alfalfa cropping. The topsoil exchangeable $\mathrm{K}$ decreased due to alfalfa forage uptake and removal; however, the total $\mathrm{K}$ in the topsoil increased due to $\mathrm{K}$ additions from deep soil $\mathrm{K}$ taken up by the alfalfa roots and deposited in the upper strata of the soil, producing a highly crystalline illitic-like clay (Li et al. 2011).

Singh and Goulding (1997), using X-ray diffraction, looked for changes in micaceous minerals that might accompany 150 years of continuous cropping by wheat, with and without $\mathrm{K}$ fertilizer, on the Broadbalk experiment at Rothamsted, $\mathrm{UK}$, but found none, although deep plowing had changed the mineralogy and $\mathrm{K}$ 
Table 10.1 A series of $23 \mathrm{~K}$ fertilizer rate studies in corn in North Dakota, with clay mineralogy of the clay fraction and potassium feldspar content of the mineral portion of the soil. Initial pre-plant soil test $\mathrm{K}$ concentrations (1M-ammonium acetate on dry soil) are also indicated along with expected yield increase compared to the yield increase experienced

\begin{tabular}{|c|c|c|c|c|c|}
\hline Site, year & $\begin{array}{l}\mathrm{K} \text { test } \\
\left(\mathrm{mg} \mathrm{kg}^{-1}\right)\end{array}$ & $\begin{array}{l}\text { Expected yield } \\
\text { increase }\end{array}$ & $\begin{array}{l}\text { Actual yield } \\
\text { increase }\end{array}$ & $\begin{array}{l}\text { Potassium } \\
\text { feldspar }(\%)\end{array}$ & $\begin{array}{l}\text { Smectite- } \\
\text { illite (\%) }\end{array}$ \\
\hline $\begin{array}{l}\text { Buffalo, } \\
2014\end{array}$ & 100 & Y & $\mathbf{N}$ & 7.1 & $85-11$ \\
\hline $\begin{array}{l}\text { Walcott E, } \\
2014\end{array}$ & 100 & $\mathrm{Y}$ & $\mathrm{Y}$ & 5.8 & $84-13$ \\
\hline $\begin{array}{l}\text { Wyndmere, } \\
2014\end{array}$ & 100 & $\mathbf{Y}$ & $\mathbf{N}$ & 6.1 & $72-22$ \\
\hline $\begin{array}{l}\text { Milnor, } \\
2014\end{array}$ & 100 & Y & $\mathbf{N}$ & 11.7 & $35-57$ \\
\hline $\begin{array}{l}\text { Gardner, } \\
2014\end{array}$ & 115 & $\mathrm{Y}$ & $\mathrm{Y}$ & 5.3 & $76-20$ \\
\hline $\begin{array}{l}\text { Fairmount, } \\
2014\end{array}$ & 140 & Y & $\mathbf{N}$ & 8.0 & $80-14$ \\
\hline $\begin{array}{l}\text { Walcott W, } \\
2014\end{array}$ & 80 & Y & $\mathbf{N}$ & 7.3 & $52-40$ \\
\hline Arthur, 2014 & 170 & $\mathbf{N}$ & $\mathbf{Y}$ & 1.7 & $85-11$ \\
\hline $\begin{array}{l}\text { Valley City, } \\
2014\end{array}$ & 485 & $\mathrm{~N}$ & $\mathrm{~N}$ & 9.0 & $70-23$ \\
\hline Page, 2014 & 200 & $\mathrm{~N}$ & $\mathrm{~N}$ & 5.7 & $74-20$ \\
\hline $\begin{array}{l}\text { Absaraka, } \\
2015\end{array}$ & 113 & $\mathbf{Y}$ & $\mathbf{N}$ & 9.9 & $84-14$ \\
\hline Arthur, 2015 & 125 & $\mathrm{Y}$ & $\mathrm{Y}$ & 9.5 & $85-12$ \\
\hline $\begin{array}{l}\text { Barney, } \\
2015\end{array}$ & 170 & $\mathrm{~N}$ & $\mathrm{~N}$ & 6.3 & $79-16$ \\
\hline $\begin{array}{l}\text { Casino, } \\
2015\end{array}$ & 120 & $\mathrm{Y}$ & $\mathrm{Y}$ & 6.4 & $85-12$ \\
\hline $\begin{array}{l}\text { Dwight, } \\
2015\end{array}$ & 110 & Y & $\mathrm{N}$ & 6 & $82-15$ \\
\hline $\begin{array}{l}\text { Fairmount1, } \\
2015\end{array}$ & 188 & $\mathbf{N}$ & $\mathbf{Y}$ & 5.6 & $87-10$ \\
\hline $\begin{array}{l}\text { Fairmount2, } \\
2015\end{array}$ & 118 & $\mathbf{N}$ & $\mathbf{Y}$ & 7.4 & $79-12$ \\
\hline $\begin{array}{l}\text { Leonard N, } \\
2015\end{array}$ & 380 & $\mathrm{~N}$ & $\mathrm{~N}$ & 6.9 & $70-25$ \\
\hline $\begin{array}{l}\text { Leonard S, } \\
2015\end{array}$ & 190 & $\mathrm{~N}$ & $\mathrm{~N}$ & 5.5 & $52-41$ \\
\hline $\begin{array}{l}\text { Milnor, } \\
2015\end{array}$ & 118 & $Y$ & $\mathrm{Y}$ & 8.6 & $74-20$ \\
\hline $\begin{array}{l}\text { Prosper, } \\
2015\end{array}$ & 205 & $\mathrm{~N}$ & $\mathrm{~N}$ & 9.2 & $83-14$ \\
\hline $\begin{array}{l}\text { Valley City, } \\
2015\end{array}$ & 200 & $\mathrm{~N}$ & $\mathrm{~N}$ & 5.6 & $65-30$ \\
\hline $\begin{array}{l}\text { Walcott, } \\
2015\end{array}$ & 109 & $Y$ & $\mathrm{Y}$ & 6.2 & $47-48$ \\
\hline
\end{tabular}

Bold font denotes site where expected yield response or nonresponse was not recorded 


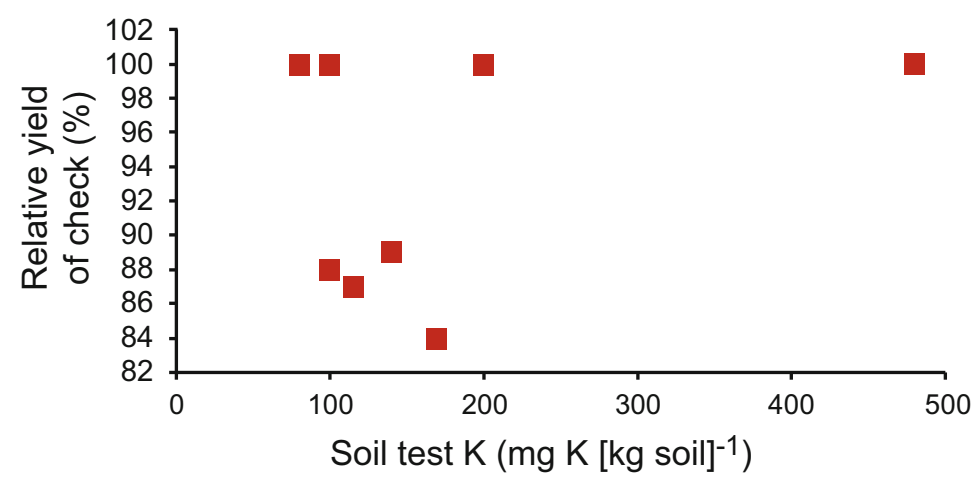

Fig. 10.7 Relative yield of check (with no added K) in North Dakota K fertilizer rate studies in 2014 and the relationship to soil test $\mathrm{K}$

Table 10.2 Multiple linear regression of possible factors relating to relative corn grain yield of 2014 and $2015 \mathrm{~K}$ fertilizer rate trials in North Dakota from Table 10.1

\begin{tabular}{l|c|c|c|c}
\hline Factor & K test & K-feldspar & Illite & Smectite \\
\hline K test & 1.0 & & & \\
\hline K-feldspar & 0.17 & 1.0 & & \\
\hline Illite & -0.03 & -0.32 & 1.0 & \\
\hline Smectite & 0.05 & 0.33 & -0.99 & 1.0 \\
\hline Relative yield & 0.29 & -0.0002 & 0.32 & -0.25
\end{tabular}

content of the surface $(0-23 \mathrm{~cm})$ soil. Evidence for changes in illite with $\mathrm{K}$ additions and losses through cropping was found from examination of long-term treatments in the Morrow Plots at the University of Illinois Experiment Station at Urbana, Illinois, USA (Velde and Peck 2002). Soil samples from the plots were archived from 1913. The differences in clay mineralogy between 1913 and 1996 indicate changes in clay mineralogy with cropping. These changes were small in the corn-oats-hay rotations, but there was a significant loss of illitic clay from the continuous corn rotation with no amendments. The authors considered that the stability of illite/smectite under the corn-oats-hay rotations was the result of $\mathrm{K}$ inputs from non-clay $\mathrm{K}$-containing minerals restoring the $\mathrm{K}$ lost from the clay minerals under this less intense cropping system. The use of NPK fertilizer was adopted in 1955, and this restored the illite content of the clay mineralogy in the continuous corn plots to what was measured in 1913. The authors speculated that the addition of K replenished the clay mineral K, stabilizing and restoring illite/smectite integrity. The illites/smectites serve as a reservoir of $\mathrm{K}$ in prairie soils, but the clays can be degraded under continuous cropping.

Previous (Clover and Mallarino 2009) and ongoing unpublished work in Iowa has shown that in smectite-dominant soils (but with smaller contents of illite and vermiculite), the measurement of both soil-test $\mathrm{K}$ and non-exchangeable $\mathrm{K}$ explains the effects of $\mathrm{K}$ additions and removal by corn and soybean on post-harvest soil $\mathrm{K}$. Also, more rapid than expected relative changes between exchangeable $\mathrm{K}$ and a combination of interaction with $\mathrm{K}$ in neoformed secondary minerals, structural $\mathrm{K}$ in 

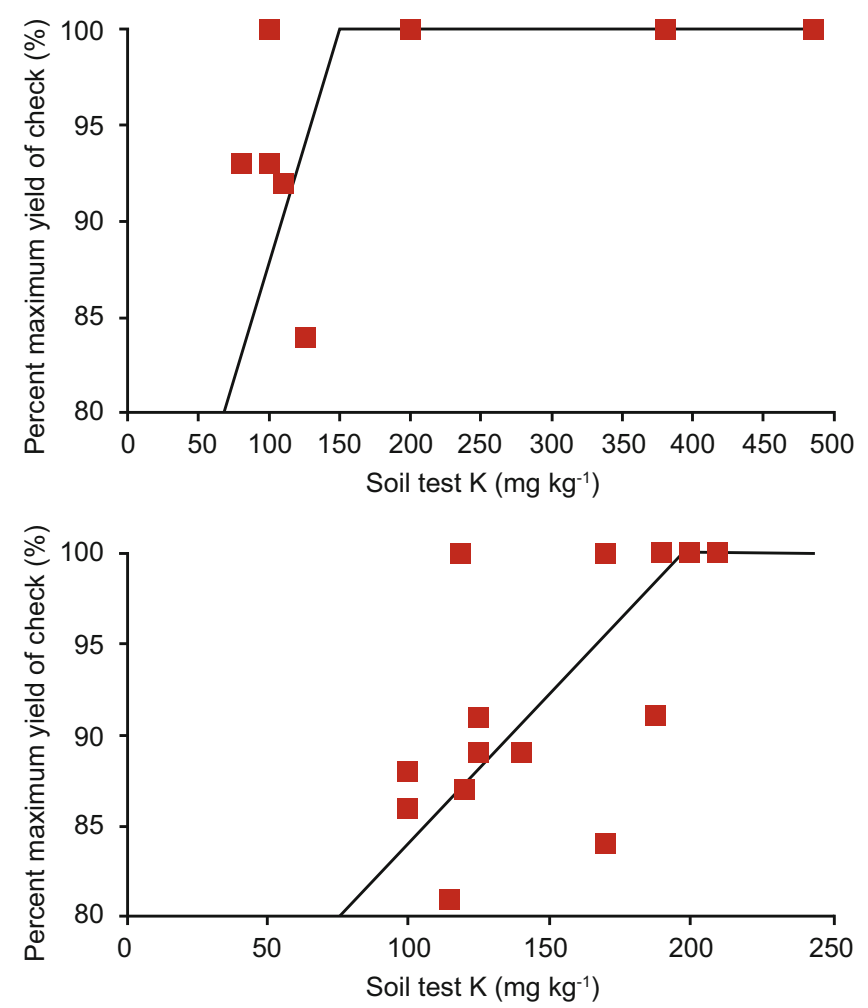

Fig. 10.8 Percent maximum corn check yields in North Dakota K fertilizer rate studies at sites with smectite/illite ratio $<3.5$ (top), and smectite/illite ratio $>3.5$ (bottom) (Franzen, unpublished data)

feldspars, interlayer $\mathrm{K}$ in micas and partially weathered micas, and interlayer $\mathrm{K}$ in secondary layered silicates explained part of the soil $\mathrm{K}$ variation between one crop and the next.

An important review of K chemistry was presented by Sparks and Huang (1985). One of the main points of their review was to highlight experiments in which the replenishment of $\mathrm{K}$ in the soil solution from non-exchangeable $\mathrm{K}$ in clays and potassium feldspars was measured in hours and days, i.e., was fast enough to meet crop needs (see also Krauss and Johnston 2002). They also noted that wetting and drying affects the movement of $\mathrm{K}$ in and out of clay interlayers. Soil wetness increases the content of reduced iron within the clay interlayers, which has a large hydrated radius. The larger radius facilitates the movement of $\mathrm{K}^{+}$out of the clay interlayers. Dry soil increases the concentration of oxidized iron within the clay interlayers, blocking the outflow of $\mathrm{K}^{+}$from the clays.

Some soils retain $\mathrm{K}^{+}$on drying, including smectitic soils in temperate regions (e.g., Barbagelata and Mallarino 2012) due to increased soil solution K concentration pushing the equilibrium between the soil solution and the soil clay in the direction of interlayer $\mathrm{K}^{+}$(Dowdy and Hutcheson 1963). 


\subsection{Relative Unresponsiveness in K Removal in Harvested Grain, Despite Wide Variability in Crop K Status and Responsiveness to K Fertilizer Application}

Variation in grain, seed, or kernel $\mathrm{K}$ concentration of eight crops was analyzed as a function of crop yield response to increasing soil exchangeable $\mathrm{K}$ in a long-term field experiment on an Oxisol soil in Queensland, Australia (Bell et al. 2009). Despite large yield responses to increasing soil $\mathrm{K}$ availability in most crops (3-10-fold range in yields of cottonseed and peanut kernels, and nearly twofold ranges in yields of wheat and sorghum), there was effectively no variation in $\mathrm{K}$ concentration in the harvested product. The lack of change in corn grain $\mathrm{K}$ concentration despite variation in soil K availability was also observed by Oltmans and Mallarino (2015). There is, however, large species variation in the rate of $\mathrm{K}$ removal (e.g., removal of $\mathrm{K}$ in soybean grain is about 5 times the rate of removal in sorghum grain-Table 10.3). This means that growers can budget to replace $\mathrm{K}$ removal in a crop rotation reasonably accurately-something that is harder to do in other nutrients where both yield and grain concentration vary in response to differences in soil supply.

Table 10.3 Response of grain/seed/kernel yield of different crops to soil K supply grown in a strongly K-limiting soil or a soil with excess $\mathrm{K}$ supply, and the resulting variation in $\mathrm{K}$ concentration in grain/seed

\begin{tabular}{|c|c|c|c|c|c|}
\hline \multirow[b]{2}{*}{ Crop } & \multirow[b]{2}{*}{$\begin{array}{l}\text { Harvested } \\
\text { portion }\end{array}$} & \multicolumn{2}{|c|}{ Strongly K-limited soil } & \multicolumn{2}{|c|}{ Excess soil K supply } \\
\hline & & $\begin{array}{l}\text { Yield } \\
\left(\mathrm{kg} \mathrm{ha}^{-1)}\right.\end{array}$ & $\begin{array}{l}\text { Seed/grain/ } \\
\text { kernel K }\left(\mathrm{g} \mathrm{kg}^{-1}\right)\end{array}$ & $\begin{array}{l}\text { Yield } \\
\left(\mathrm{kg} \mathrm{ha}^{-1}\right)\end{array}$ & $\begin{array}{l}\text { Seed/grain/ } \\
\text { kernel K }\left(\mathrm{g} \mathrm{kg}^{-1}\right)\end{array}$ \\
\hline Corn (Zea mays L.) & Grain & 4200 & 2.7 & 6240 & 2.9 \\
\hline $\begin{array}{l}\text { Sorghum (Sorghum } \\
\text { bicolor L.) }\end{array}$ & Grain & 5210 & 3.4 & 8690 & 3.2 \\
\hline $\begin{array}{l}\text { Wheat (Triticum } \\
\text { aestivum L.) }\end{array}$ & Grain & 3700 & 3.9 & 5710 & 3.7 \\
\hline $\begin{array}{l}\text { Cotton (Gossypium } \\
\text { hirsutum L.) }\end{array}$ & Seed & 380 & 8.9 & 3840 & 8.8 \\
\hline $\begin{array}{l}\text { Peanut (Arachis } \\
\text { hypogaea L.) }\end{array}$ & Kernel & 810 & 6.9 & 2720 & 7.0 \\
\hline $\begin{array}{l}\text { Chickpea (Cicer } \\
\text { arietinum L.) }\end{array}$ & Grain & 2220 & 8.1 & 3010 & 8.5 \\
\hline $\begin{array}{l}\text { Mungbean (Vigna } \\
\text { radiata L.) }\end{array}$ & Grain & 1150 & 13.1 & 1706 & 11.7 \\
\hline $\begin{array}{l}\text { Soybean (Glycine } \\
\max \text { L. Merr.) }\end{array}$ & Grain & 2170 & 16.3 & 3270 & 16.5 \\
\hline
\end{tabular}

From a long-term experiment on an Oxisol near Queensland, Australia, described in Bell et al. (2009) 


\subsection{Potassium Losses Due to Erosion from Wind and Water}

A seldom considered source of $\mathrm{K}$ loss that may contribute to regional $\mathrm{K}$ balance is the loss of topsoil due to wind and water erosion. An analysis of nutrient losses in North Dakota from the time of first plowing (1880 through 1920, depending on the location within the state) is underway, and complete for phosphorus (P). Total P loss from wind erosion in North Dakota since the time of plowing is estimated to be $17 \mathrm{M}$ tons of P (Franzen 2016). This is equivalent to over 200 years of $\mathrm{P}$ application by North Dakota farmers to the $10 \mathrm{M}$ ha of state cropland at fertilizer rates commonly applied in 2016. Total $\mathrm{K}$ loss from wind erosion since plowing is estimated to be much higher. Analysis of dust originating from North Dakota topsoil collected in eastern US cities in the 1930s contained 19 times more $\mathrm{P}$ and 45 times more $\mathrm{K}$ than samples obtained in regions of origin after the storms (Hansen and Libecap 2004). Topsoil loss in large portions of the state not under no-till or modified no-till systems is still on-going. A site northwest of Grand Forks, ND characterized in 1958 and re-characterized in 2014 revealed $48 \mathrm{~cm}$ of topsoil loss due to wind erosion over the 56 years (Montgomery 2015).

\subsection{Summary}

The mass balance of $\mathrm{K}$ in the surface soil is a function of: (1) $\mathrm{K}$ added in fertilizers and manures; (2) plant redistribution of subsoil K to the surface; (3) K losses due to leaching in low CEC soils, and sampling to deeper depths than the $0-15 \mathrm{~cm}$ depth to determine subsoil contribution; (4) K removal with grain, forage, and crop residues; and (5) $\mathrm{K}$ lost in soil erosion from wind/water. A mass-balance relationship based on the measurement of exchangeable $\mathrm{K}$ is only rarely achieved because of the rapid equilibrium between soil solution $\mathrm{K}$ and its relatively rapid exchange with $\mathrm{K}$ in $\mathrm{K}$-bearing primary minerals and clay interlayers. In addition, soil moisture, temporal differences in exchangeable $\mathrm{K}$ with $\mathrm{K}$ uptake by crops, $\mathrm{K}$ leaching from residues, clay type, organic matter contributions to the soil CEC and type of $\mathrm{K}$ amendment have confounded many attempts to relate $\mathrm{K}$ additions and losses with $\mathrm{K}$ soil test. Research is needed to create regionally specific $\mathrm{K}$ soil test procedures that can predict crop response within a subset of clays and K-bearing minerals within specific cropping systems.

\section{References}

Addiscott TM, Johnston AE (1971) Potassium in soils under different cropping systems 2. The effects of cropping systems on the retention by the soils of added K not used by crops. J Agr Sci Camb 76:553-561. https://doi.org/10.1017/S0021859600069550

Albrecht WA (1975) The Albrecht papers. Vol 1: Foundation concepts. Acres USA, Kansas City 
Alfaro MA, Jarvis SC, Gregory PJ (2004) Factors affecting potassium leaching in different soils. Soil Use Manage 20:182-189. https://doi.org/10.1111/j.1475-2743.2004.tb00355.x

Barbagelata PA, Mallarino AP (2012) Field correlation of potassium soil test methods based on dried and field-moist soil samples for corn and soybean. Soil Sci Soc Am J 77:318-327. https:// doi.org/10.2136/sssaj2012.0253

Barre P, Velde B, Abbadie L (2007) Dynamic role of 'illite-like' clay minerals in temperate soils: facts and hypotheses. Biogeochemistry 82:77-88. https://doi.org/10.1007/s10533-006-9054-2

Barre P, Berger G, Velde B (2009) How element translocation by plants may stabilize illitic clays in the surface of temperate soils. Geoderma 151:22-30. https://doi.org/10.1016/j.geoderma.2009. 03.004

Bell MJ, Moody PW, Harch GR, Compton B, Want PS (2009) Fate of potassium fertilisers applied to clay soils under rainfed grain cropping in south-east Queensland, Australia. Aust J Soil Res 47:60-73. https://doi.org/10.1071/SR08088

Bell MJ, Mallarino AP, Moody P, Thompson M, Murrell S (2017a) Soil characteristics and cultural practices that influence potassium recovery efficiency and placement decisions. In: Proceedings of the frontiers of potassium workshop, Rome, Italy, 25-27 Jan 2017. https://www.apni.net/kfrontiers/ . Accessed 29 May 2020

Bell MJ, Ransom MD, Thompson ML, Florence AM, Moody PW, Guppy CN (2017b) Soil potassium pools with dissimilar bioavailability. In: Proceedings of the frontiers of potassium workshop, Rome, Italy, 25-27 Jan 2017. https://www.apni.net/k-frontiers/. Accessed 29 May 2020

Blake L, Mercik S, Koerschens M, Goulding KWT, Stempen S, Weigel A, Poulton PR, Powlson DS (1999) Potassium content in soil, uptake in plants and the potassium balance in three European long-term field experiments. Plant Soil 216:1-14. https://doi.org/10.1023/ A: 1004730023746

Buchholz DD (2004) Soil test interpretations and recommendations handbook. Univ. of Missouri College of Agriculture, Division of Plant Sciences, Columbia, MO. http://aes.missouri.edu/pfcs/ soiltest.pdf. Accessed 12 May 2020

Clover MW, Mallarino AP (2009) Potassium removal and post-harvest soil potassium fractions in corn-soybean rotations as affected by fertilization. In: Agronomy abstracts. CD-ROM. ASA-CSSA-SSSA, Madison, WI

Cope JT Jr (1981) Effects of 50 years of fertilization with phosphorus and potassium on soil test levels and yields at six locations. Soil Sci Soc Am J 45:342-347. https://doi.org/10.2136/ sssaj1981.03615995004500020023x

Dobermann A, Cassman KG, Sta CPC, Adviento MAA, Pampolino MF (1996) Fertilizer inputs, nutrient balance, and soil nutrient-supplying power in intensive, irrigated rice systems. II: Effective soil K-supplying capacity. Nutr Cycl Agroecosyst 46:11-21. https://doi.org/10. 1007/BF00210220

Dowdy RH, Hutcheson TB (1963) Effect of exchangeable potassium level and drying on release and fixation of potassium by soils as related to clay mineralogy. Soil Sci Soc Am J 27:31-34. https://doi.org/10.2136/sssaj1963.03615995002700010014x

Fernandez F, Hoeft RG (2015) Illinois agronomy handbook. Chapter 8 Managing soil pH and crop nutrients. http://extension.cropsciences.illinois.edu/handbook/pdfs/chapter08.pdf. Accessed 12 May 2020

Franzen DW (1993) Spatial variability of plant nutrients in two Illinois fields. PhD Dissertation, University of Illinois, Urbana, IL. http://hdl.handle.net/2142/72615 . Accessed 12 May 2020

Franzen DW (2011) Variability of soil test potassium in space and time. In: Proceedings of the North Central extension industry soil fertility conference, 16-17 Nov 2011. Des Moines, IA. IPNI, Brookings, SD, pp 74-82

Franzen DW (2016) A history of phosphate export from North Dakota and the region. https://www. youtube.com/watch? $\mathrm{v}=\mathrm{vQF0hy} 2 \mathrm{crH} 0 \&$ feature=youtu.be. Accessed 12 May 2020 
Goulding KWT (1984) The availability of potassium in soils to crops as measured by its release to a calcium-saturated cation exchange resin. J Agric Sci Camb 103:265-275. https://doi.org/10. 1017/S0021859600047213

Goulding KWT, Loveland PJ (1986) The classification and mapping of potassium reserves in soils of England and Wales. J Soil Sci 37:555-565. https://doi.org/10.1111/j.1365-2389.1986. tb00387.x

Graham ER (1959) An explanation of theory and methods of soil testing. Bull. 734. Missouri Agr Exper Station, Columbia

Hansen ZK, Libecap GD (2004) Small farms, externalities and the Dust Bowl of the 1930's. J Polit Econ 112:665-694. https://doi.org/10.1086/383102

Jobbagy EG, Jackson RB (2004) The uplift of soil nutrients by plants: Biogeochemical consequences across scales. Ecology 85:2380-2389. https://doi.org/10.1890/03-0245

Kopittke PM, Menzies NW (2007) A review of the use of the basic cation saturation ratio and the 'ideal' soil. Soil Sci Soc Am J 71:259-265. https://doi.org/10.2136/sssaj2006.0186

Krauss A Johnston AE (2002) Assessing soil potassium, can we do better? In: 9th International congress of soil science, Faisalabad, Pakistan, 18-20 Mar 2002. https://doi.org/10.3923/ijss. 2016.36.48

Li DC, Velde B, Li FM, Zhang GL, Zhao MS, Huang LM (2011) Impact of long-term alfalfa cropping on soil potassium content and clay minerals in a semi-arid loess soil in China. Pedosphere 21:522-531. https://doi.org/10.1016/S1002-0160(11)60154-9

McEwen J, Johnston AE, Poulton PR, Yeoman DP (1984) Rothamsted garden clover - red clover grown continuously since 1854 . Yields, crop and soil analyses 1956-1982. Rothamsted Report for 1983, pp 225-237. https://doi.org/10.23637/ERADOC-1-34111

Mendes W da C, Junior JA, da Cunha PCR, da Silva AR, Evangelista AWS, Casaroli D (2016) Potassium leaching in different soils as a function of irrigation depths. Rev Bras Eng Agr Amb 20:972-977. https://doi.org/10.1590/1807-1929/agriambi.v20n11p972-977

Miles N, van Antwerpen, R, Fey M, Edmeades D, Farina M, Lambrechts JJN, Hoffman JE, HardiePieters AG, Clarke CE, Rozanov DA, Ellis F, du Preez CC, Manson A., Thibaud G, Roberts V (2013) The Albrecht System: uneconomical and outdated! Farmers Weekly, 24 May 2013, pp 8-9. http://www.farmersweekly.co.za/opinion/by-invitation/the-albrecht-system-uneconomi cal-outdated/ . Accessed 12 May 2020

Montgomery BL (2015) Evaluating dynamic soil change in the Barnes soil series across eastern North Dakota. MS Thesis. 521 pages. North Dakota State University, Fargo, ND. http://search. proquest.com/docview/1686112990. Accessed 12 May 2020

Oltmans RR, Mallarino AP (2015) Potassium uptake by corn and soybean, recycling to soil, and impact on soil test potassium. Soil Sci Soc Am J 79:314-327. https://doi.org/10.2136/sssaj2014. 07.0272

Peck TR, Sullivan ME (1995) Twice monthly field soil sampling for soil testing to evaluate reproducibility of soil test levels. In: Illinois fertilizer conference proceedings, 22-25 Jan 1995

Potash Development Association (2011) Soil analysis. Key to nutrient management planning. The Potash Development Association, Leaflet 24. Middlesbrough, UK. http://www.pda.org.uk/pda_ leaflets/24-soil-analysis-key-to-nutrient-management-planning/. Accessed 12 May 2020

Sharpley AN (1989) Relationship between soil potassium forms and mineralogy. Soil Sci Soc Am J 53:1023-1028. https://doi.org/10.2136/sssaj1989.03615995005300040006x

Singh B, Goulding KWT (1997) Changes with time in the potassium content and phyllosilicates in the soil of the Broadbalk continuous wheat experiment at Rothamsted. Eur J Soil Sci 48:651-659. https://doi.org/10.1111/j.1365-2389.1997.tb00565.x

Sparks DL, Huang PM (1985) Physical chemistry of soil potassium. In: Munson RD (ed) Potassium in agriculture. ASA, CSSA, SSSA, Madison, WI, pp 201-276. https://doi.org/10.2134/1985. potassium

Steiner FM, Lana M do C, Zoz T, Frandoloso JF (2015) Changes in potassium pools in Paraná soils under successive cropping and potassium fertilization. Semin Cienc Agrar 36:4083-4098. https://doi.org/10.5433/1679-0359.2015v36n6Supl2p4083 
Velde B, Peck T (2002) Clay mineral changes in the Morrow Experimental Plots, University of Illinois. Clay Miner 50:364-370. https://doi.org/10.1346/000986002760833738

Villavicencio CX (2011) Relationships between potassium fertilization, removal with harvest, and soil-test potassium in corn-soybean rotations. Iowa State University Graduate Theses and Dissertations.

http://lib.dr.iastate.edu/cgi/viewcontent.cgi?article $=1150 \&$ context $=$ etd. Accessed 12 May 2020

Wang FL, Huang PM (2001) Effects of organic matter on the rate of potassium adsorption by soils. Can J Soil Sci 81:325-330. https://doi.org/10.4141/S00-069

Open Access This chapter is licensed under the terms of the Creative Commons Attribution 4.0 International License (http://creativecommons.org/licenses/by/4.0/), which permits use, sharing, adaptation, distribution and reproduction in any medium or format, as long as you give appropriate credit to the original author(s) and the source, provide a link to the Creative Commons license and indicate if changes were made.

The images or other third party material in this chapter are included in the chapter's Creative Commons license, unless indicated otherwise in a credit line to the material. If material is not included in the chapter's Creative Commons license and your intended use is not permitted by statutory regulation or exceeds the permitted use, you will need to obtain permission directly from the copyright holder. 